\title{
A Symbolic Analysis of the Islamic Period Gravestones in the Ahar Museum
}

\author{
Mehdi Kazempour $^{1} \cdot$ Shahriyar Shokrpour ${ }^{1}$
}

Accepted: 6 January 2021 / Published online: 26 March 2021

(C) The Author(s) 2021

\begin{abstract}
The Ahar city not only has a large number of historical cemeteries but also the courtyard of the city's museum has one of the richest Islamic-era gravestone collections. These gravestones date to the thirteenth-eighteenth centuries and have been collected from inside the city as well as from surrounding villages. The present study analyzes these gravestones based on a symbolic approach. In this paper, we will answer the question: What are the symbolic meanings of the decorations on the Ahar Museum gravestones? We conclude that various motifs appear, including inscriptions, geometric designs, and allegorical, military, and narrative scenes. These motifs directly relate to the beliefs of the people who created them.
\end{abstract}

Keywords Symbolism · Gravestone · Decorative motifs · Concepts of belief

\section{Introduction}

The cemetery can be considered a cultural manifestation of people's attitude to the phenomenon of death (Balilan Asl and Doustar 2015). In the Islamic period, the construction of religious buildings grew in parallel with the manifestation of beliefs and practices related to the protection of the dead. Cemeteries became important (Shahinizad 2011) and the building of shrines increased. The various methods of constructing such monuments, structurally influenced by cultural and material factors, are in line with the religion and beliefs of the society. While the issue of mosque rulings in Islamic jurisprudence has differing opinions, the presence of a large number of such buildings in many Islamic countries reflects the particular status of this structure in the

Mehdi Kazempour

M.kazempour@Tabriziau.ac.ir

Shahriyar Shokrpour

Sh.Shokrpour@Tabriziau.ac.ir

1 Islamic Crafts Art Faculty, Tabriz Islamic Art Faculty, Tabriz, Eastern Azerbaijan Province, Iran 
Islamic society. In Iran from second century AH (719-816 CE), the use of gravestones proliferated with the emergence of various local dynasties in the east and north of Iran and continued throughout the following periods. The important point regarding these structures is the relationship between the deceased person and their structural and decorative features; that is, that ordinary people had better reputations than prominent people and thus better tombstones. Soon after, cemeteries became religious collections of numerous monuments (Kazempour et al. 2021).

Azerbaijan during the seventh and eighth centuries $\mathrm{AH}$ (thirteen and fourteen century CE) was one of the important centers of Sufism. It has particular importance with regard to the centrality of the rule of the Ilkhanid in the Azerbaijan area, and the special attention the Mongol rulers gave to mystics and elders. Stone graves were made with special characteristics for the deceased. A certain style of gravestone and burial architecture evolved, and their foundations are rooted in Islamic Sufism, especially Sheikh Zahed Gilani and Sheikh Safieddin Ardebili, mystics of the seventh and eighth centuries (Hosaini 2009). For the purpose of this study the symbolic implications of the gravestones found at the Ahar Museum, which have been collected from different parts of the city as well as surrounding villages (Bohoul Village Cemetery, Andab Cemetery, and Has village Cemetery), were selected as case studies. The number of stone carvings (both intact and fragmented) in this museum is 50 , with 25 stones containing the highest volume of symbolic information chosen as a representative sample.

\section{Methodology}

This research has a qualitative and objective purpose and its method is descriptiveanalytical. The initial stage of this research was based on field studies in which the necessary documentation, such as photography, design transcription, and reading of inscriptions and motifs, has been made. Then, after providing the descriptions, the information was analyzed through comparison with existing written sources.

\section{Background}

Gravestones are one of the most important cultural materials in the Azerbaijan region, and a wide range of them can be seen in Ardebil province. These gravestones, which have been constructed at different historical periods and in accordance with various religious and regional traditions, have not been studied by researchers because of their location and spatial dispersion. During the Pahlavi era (twentieth century) with the developments of urbanization, gravestones in the inner city and suburbs have been moved to museums from their original locations. Therefore, an important part of the art museums in East Azerbaijan province has been concerned with the preservation of these cultural materials. These artifacts can be seen today in museums. Unfortunately, not only have the Ahar city museum gravestones not been studied, the Ahar region has not been considered by researchers. It has not even been mentioned in archaeological field reports such as Wolfram Kleiss, Stephan Kroll, Jacques de Morgan, and others. The only study is an article, "the old Has village tombstones," written by Mohammad al-Wansaz-e-Khuyi (2011). This paper includes images of the Has village 
gravestones. Other studies include Mirjafari and Bazaz Dastfroush (2009), Mirjafari and Bazaz Dastfroush (2012), Kabir Saber (2012), and Balilan Asl and Doustar (2015). Our review of the history of the subject of Islamic gravestones, we conclude that the existing research has been carried out mainly with the purpose of introducing burial sites, highlighting famous people in a certain cemeteries, and in some cases, detailing decorations on the monuments. The present study, in addition to classifying the decorative motifs of the Ahar museum gravestones, also offers a symbolic approach to their study.

\section{The Dispersion of Gravestones in the Ahar Region}

Burial in graves with rocks and magnificent graves (known as Manhir and Dolman in archeology) has a long history in the Ahar region. From prehistory and coinciding with the second millennium BCE, burial was carried out in massive gravestones with rocks that were cut in the region. This type of grave has been identified based on the first archaeological activity in the Ahar region by Jacques de Morgan (1959).

In addition, based on German archaeological studies during 1967, 1968, 1971, 1977 , and 1978 in different parts of the Ahar region (gizil Gaya and Sambran Cemetery), a rich collection of the second millennium BCE materials, such as large gravestones, castles, and gray peasant pottery, were found (Kroll 1983). This type of burial consists on a rectangular grave with a structure of large rocks in the middle, with an arrangement of rocks in a circle surrounding it. On top of these graves are different types of memorial stones that seem to indicate the existence of a community with an advanced social system (Kazempour et al. 2012). This is the oldest evidence of symbolic signs on gravestone in this region. Later (1000 BCE), another type of gravestones (decorated with soldiers having abstract faces) in the Shahar Yeri Cemetery (located in Meshkinshahr, Ardebil Provinc, northwest Iran), were used (Ingraham and Sumarz 1979). Based on this information, the gravestones in the Ahar region can be divided into two categories: pre-Islamic and post-Islamic. Pre-Islamic gravestones have remained intact because they were inaccessible, being built on top of hills and mountains far from cites, but the Islamic-period gravestones, due to their locations mostly inside cities, are accessible. Development activities in cites have destroyed many of these gravestones. Others have been moved to museums.

According to archaeological field studies, three domestic regions contributed the largest number of Islamic-period gravestones: the Has village cemetery (located beside the Ahar-Kalibar road, in the north of Ahar city), with 200 Islamic middle-age gravestones, Bohoul village Cemetery (beside the Ahar-Meshkin city road, in the southwest of Ahar city) with 30 middle and latter Islamic-period gravestones, and finally, the Andab Ghadim village cemetery (located $5 \mathrm{~km}$ from west of Bohoul Village) (Fig. 1). So many of the Ahar Museum gravestones have been collected from these three areas.

\section{The Ahar Museum Gravestones}

The Ahar Museum is located in Ahar city (Eastern Azerbaijan province, northwest Iran (Figs. 2 and 3), and in its courtyard are 50 Islamic-period gravestones (Fig. 4) that, 
based on their forms, are divided into two groups: Flat rectangular and staircase box gravestones.

Flat rectangular Gravestones These types of gravestones are simple, rectangular with a short base and flat surface. They are $2 \mathrm{~m}$ long, $1 \mathrm{~m}$ wide, and $20 \mathrm{~cm}$ thick. Almost all 49 of the Ahar museum gravestones have this form. A comparative study revealed that most types of gravestones in Azerbaijan and Ardebil provinces are similar to this form. In Azerbaijan province, they are in: Bilan Kouh cemetery (in Tabriz city), (Mirjafari and Bazaz Dastfroush 2012), Tabriz Cherndab cemetery (in Tabriz city), Tabriz Pine_Shalvar Cemetery (in Tabriz city) and in Ardabil province at Shahidgah cemetery (in Ardebil City), Meshkinshahr Pomegranate, Sheikh Kalkhoran cemetery (Behshid and Bohloli Nuri 2013) (Table 1). In this type, a frame motif appears on the gravestones. The purpose of creating these frames was to define and organize space for inscriptions and decoration (Parsai and Shahabi Rad 2011).

In the Ahar Museum, these frames are in line with the design of the stones and in harmony with their dimensions. These designs and frames have three common features:

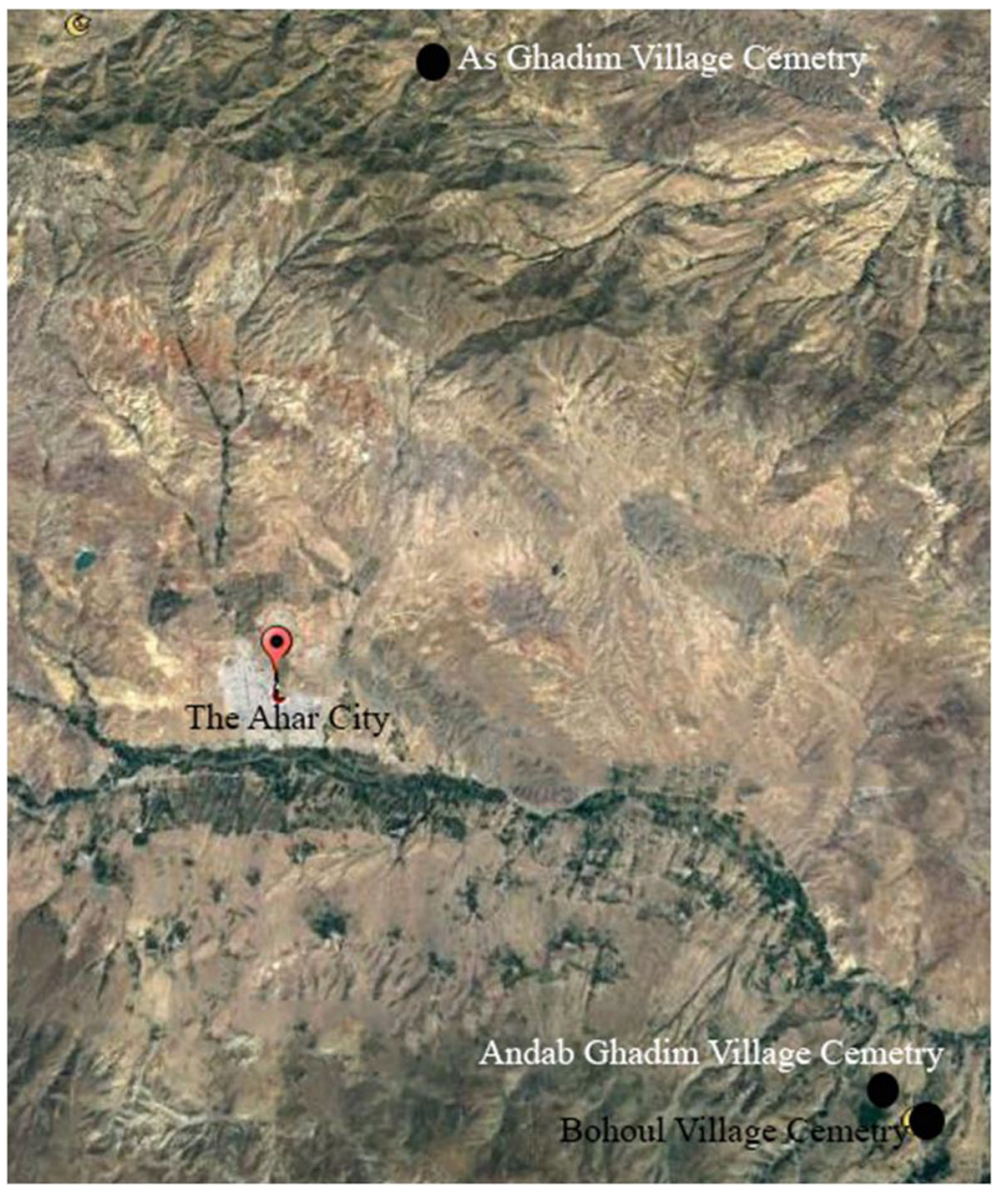

Fig. 1 The dispersion of Gravestones in the Ahar region 


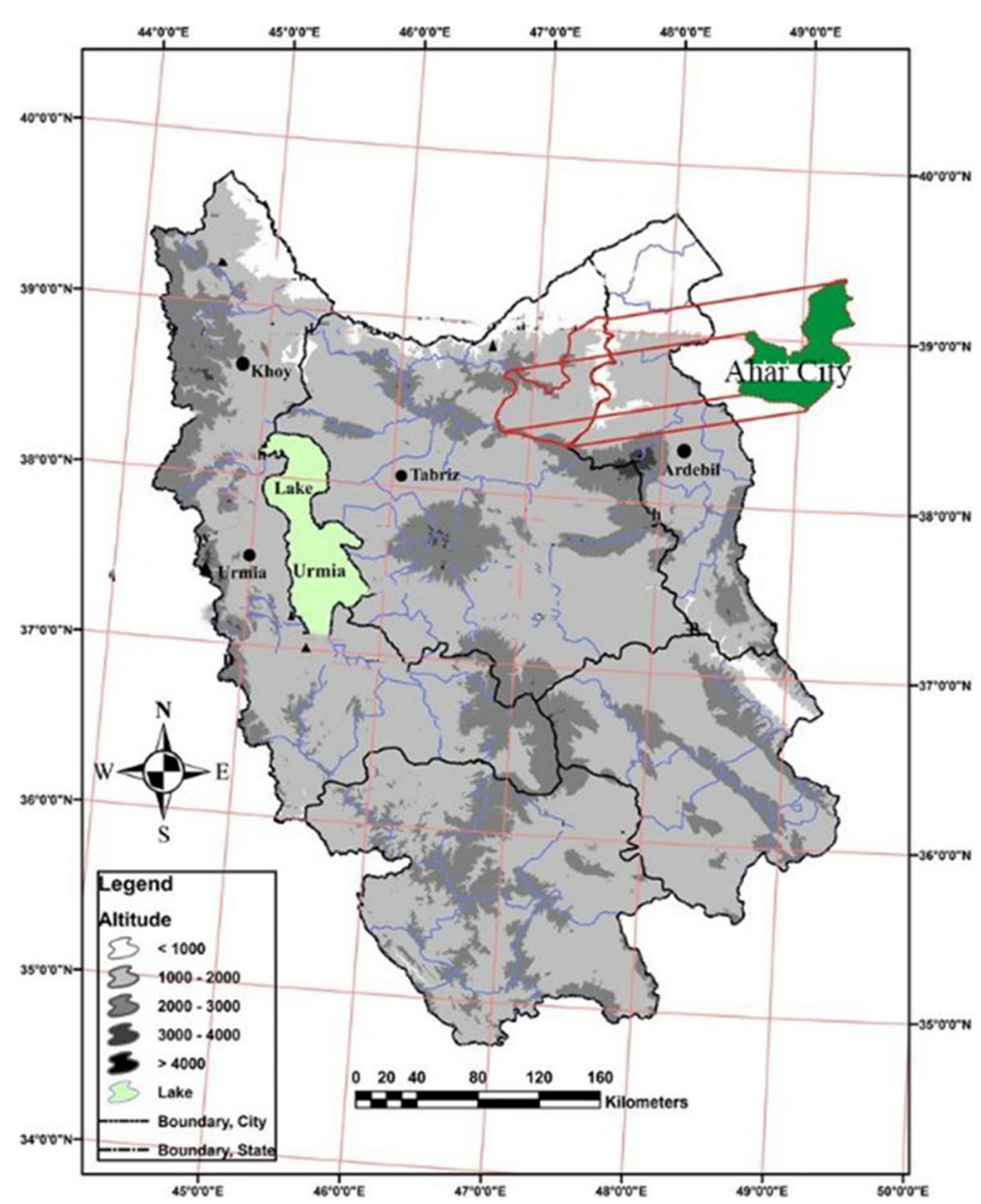

Fig. 2 The location of Ahar City

1. Like their gravestones, they are fitted and rectangular;

2. There is a line of symmetry in the longitudinal axis and rarely in the transverse axis;

3. Their shape resembles an archeological site (altar plan). This last kind of altar frame includes several types: a simple altar, a five-leaf palm pebble, and a seven-leaf palm pebble.

The script consists of two rectangular boxes. In the upper rectangle, which is much smaller, verses of the hadith or the year and the characteristics of the deceased are engraved, and in the lower rectangle, which is larger, the alphabet designs are used to create various patterns (Behshid and Bohloli Nuri 2013).

The staircase box Gravestones It is $1 \mathrm{~m}$ tall and its carving resembles a staircase. The upper bump length is slightly shorter than its base. Its surface is divided into three decorated parts. In the first and lowest part, geometric motifs have been executed. In the second or middle part, an inscription appears. This inscription contains poems, verses, 


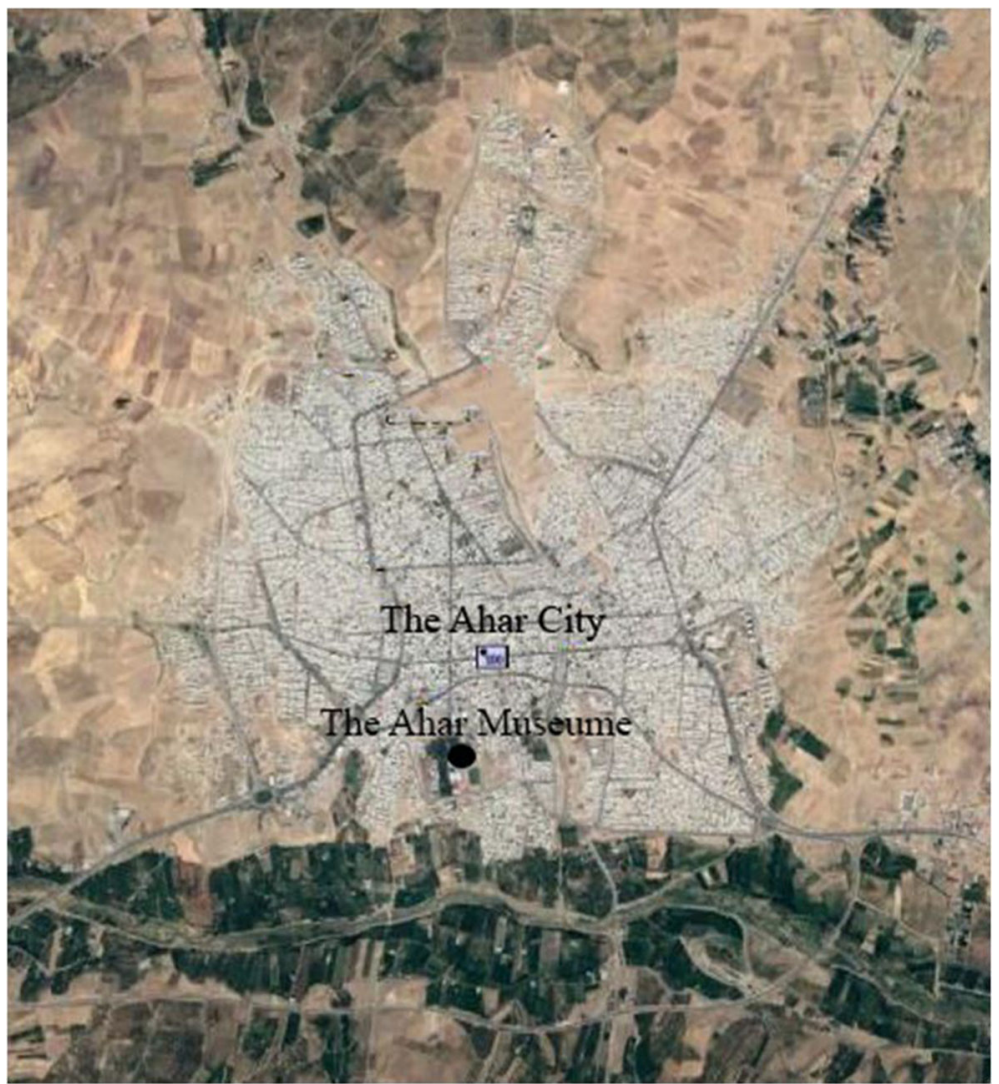

Fig. 3 The location of the Ahar Museum

or hadith written in Sol's handwriting. The upper part is shorter than the other parts, and includes the deceased's name and date of death. Similar examples of such gravestones

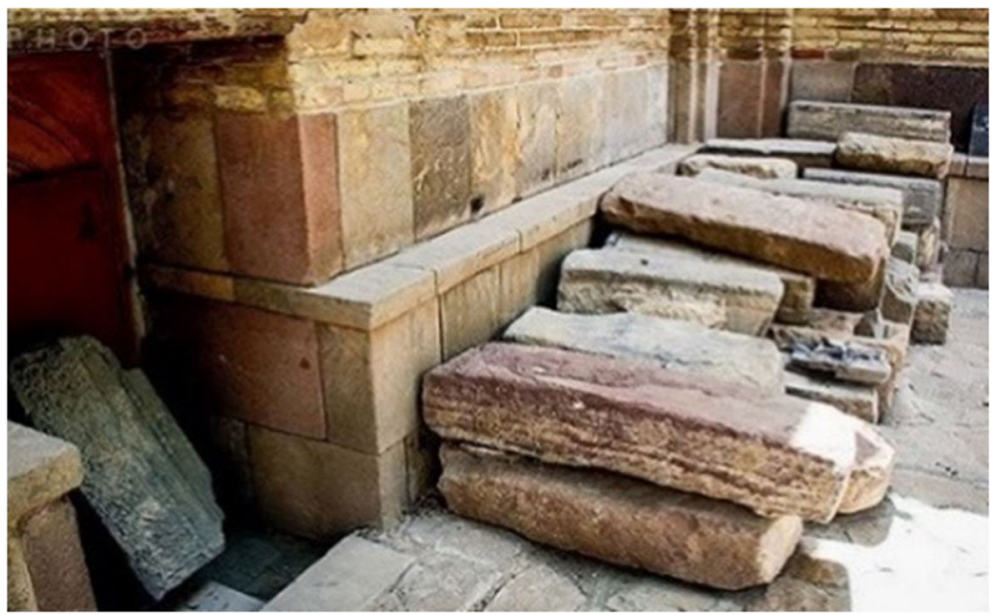

Fig. 4 Gravestons at the Ahar City museum courtyard 
Table 1 Flat stone with a seven-leaf palm pebble

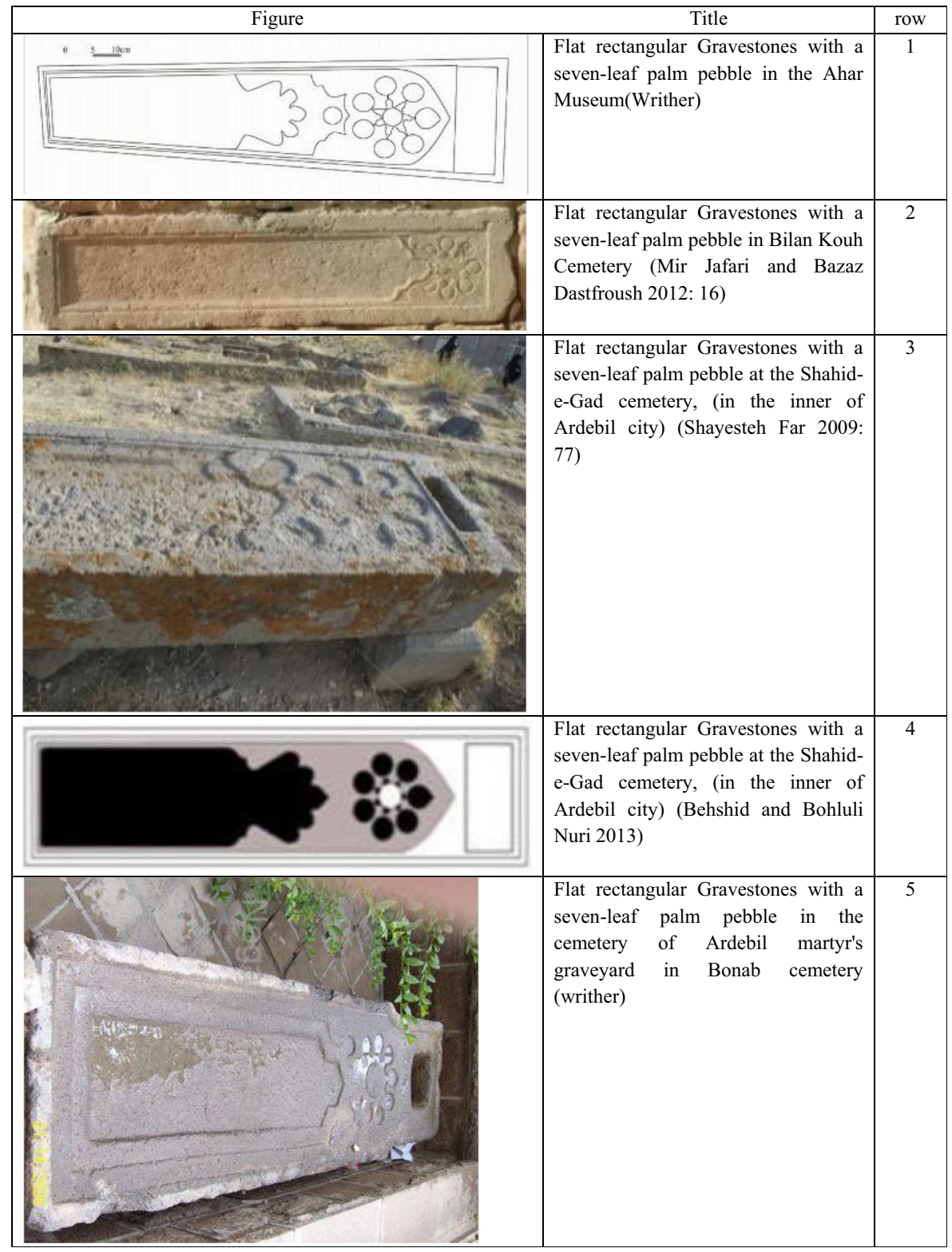

can be seen in the Golestan region (Raja'i Alavi and Vafa'I 2009), in the Bilan Kouh cemetry (Mirjafari and Bazaz Dastfroush 2012: 16), the cemetery of Khanghah village (Kuhpar et al. 2015: 145), in the Soosawa Khalkhal village cemetry, the Herris Khanqah village cemetery(Kuhpar et al. 2015: 143), the Amakhzadeh Cemetery (in Zanjan city) (Nikzad and Isa 2005: 385), and the cemetery of Kivaj Mehraban village (Kuhpar et al. 2015: 143). (Table 2). The wooden sample of this is from the 
seventeenth-century Sheikh Safi-eddin Tomb (in Ardebil City), which is located in a crypt (Hosseini 2010: 255; Kuhpar et al. 2015: 145). Staircase box gravestones have been used in the Azerbaijan province since the beginning of the eighth century $\mathrm{AH}$, and were usually made of granite stone (Kabir Saber 2009).

\section{The Symbolism of Ahar Museum Gravestones}

Artists are always inspired by and consider the philosophical justifications of their work, and they help draw images and lines to popularize their works and explain the relationships between their art and religious beliefs, immortalizing the tip of the pen on the stone. They gave spirits and freshness to rock (Safi Khani et al. 2014). In cases where the artist uses motifs to convey visually the thoughts and concepts of verbal expression and description, he places his foot on the vein of beliefs and culture. The meaning of the image, of the drawing, and of the face is specific to any given culture (Moain 1985).

The funeral as well as its related rituals is understandable as a cultural effect and is depicted in burial monuments and stone graves. Accordingly, motifs and images depicted on stone graves have two meanings: one is a literal meaning and the other is a metaphorical, codified meaning rooted in belief and tradition. The tools used by a stonemason allows for expressing concepts beyond the boundaries of verbal communication. The main features of the stone monuments in the Ahar Museum are no exception, as they display the beliefs of their contemporary makers in their designs. These images are related to a belief in the immortality of the soul and the religious beliefs of their time (Faqih Mirzaei et al. 2005: 225). The characteristics of the Ahar tombstones can be typologically described in five ways: inscriptions, geometric features, narratives (including human and animal designs), altar motifs, and weapons (bows and arrows).

Inscription motifs.

Inscriptions on gravestones are not only beautiful examples of identity, but offer written sources that can play a significant role in determining the religious, political, and artistic status of Iran in different historical periods (Edinghausen 2000: 205). Stone inscriptions usually contain religious verses, poems related to the mortal nature of the world, as well as the name of the deceased and the date of death. The inscriptions, both in terms of form and writing, introduce concepts such as monotheism, worship, moral commitment, and feelings of people toward their peripheral world. The oldest inscriptions on stone graves are found in Herat at Khajeh Abdullah Ansari, where several Timurid princes have been buried with gravestones. One of these inscriptions is dated to $882 \mathrm{AH}$ (1477 CE) (Ghalich Khani 2006: 143). Among the themes used in gravestone inscriptions are Persian poetry with mystical concepts and insights about the Muslim view of the world and an attention to piety and remembrance of God. Poets such as Sa'di, Rumi, Hafez, Anvari Jami, Qassim Anvar, and others have been found.

The inscriptions on the Ahar museum gravestone, usually written by Sols, contains a verse from the Qur'an, the hadith, a poem, and the name of the deceased. On the surface

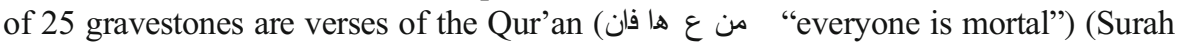

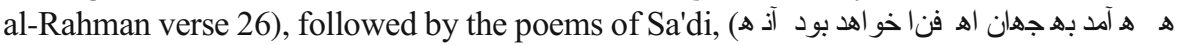
(ب) نو ندهو باق ت خدا خو اهد بود 
Table 2 Formation of the Cradle box Type Tombstone

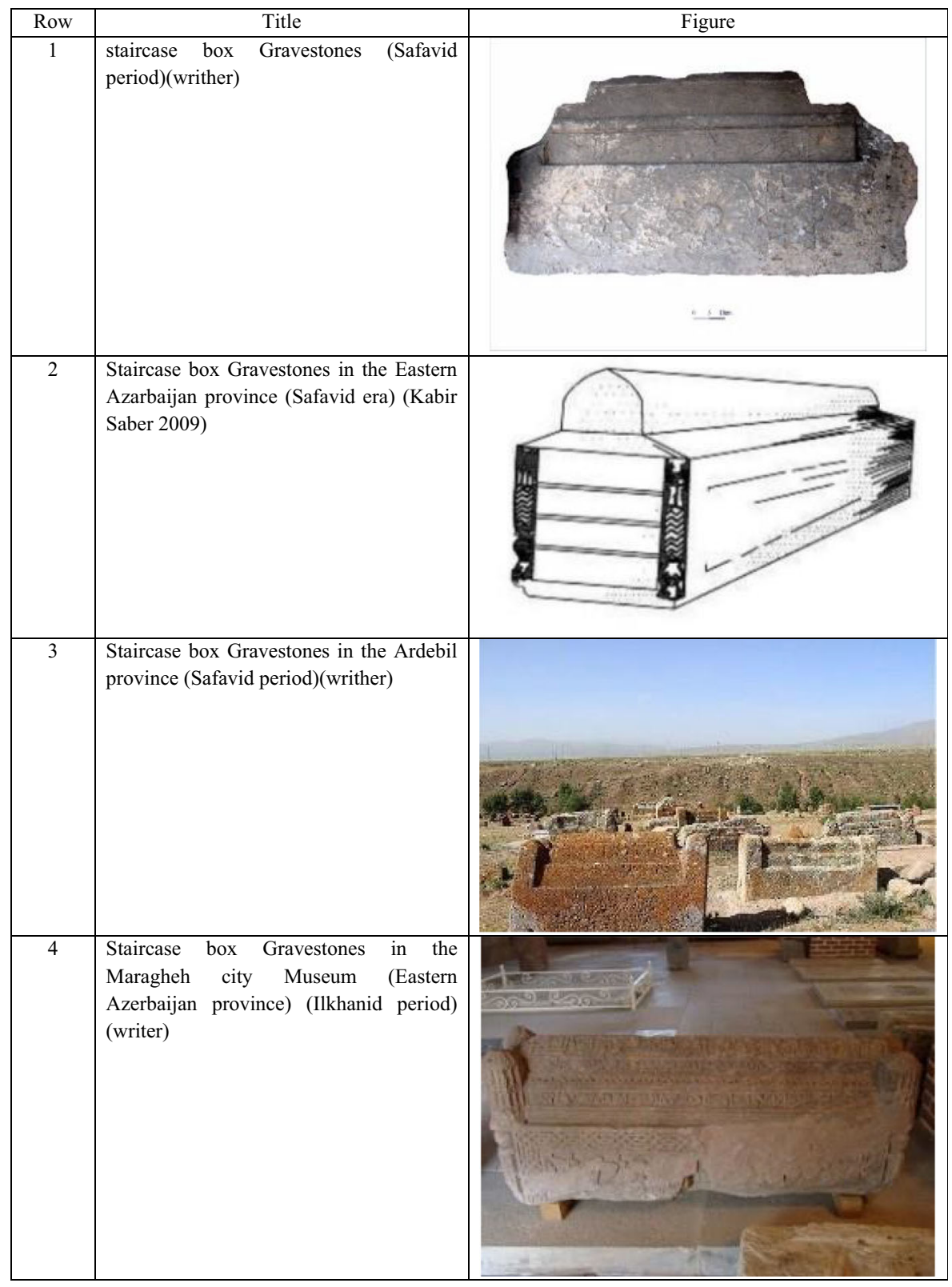

and remain, is God"), and finally the name of the deceased (Fig. 5). In one kind of gravestone, the choice of a verse from Surah al-Rahman and the poetry of Saadi has been deliberately carved out, and both mention the mortality of the earthly world and humanity. From past centuries in Iran, many of the gravestones have been written with Qur'an sentences the main text of the inscriptions, in addition to the verses of AlRahman al-Rahim and Qur'anic verses, also included verses from the Surah Yasin and 
other sources. This verse, Sharifa (verse 26 of Surah Al-Rahman), expresses the mortality of all beings on earth and addresses the reader: "you who have appeared on the grave, lest you think that you have eternal life, and you will not die, you, like the same owner of the grave that you stand beside, will have a day out of the world." This verse, as mentioned above, is accompanied by a poem from Saadi contemplating the mortality of the world. This poem from Saadi is used on gravestones in different regions in Iran such as the Hamedan Khezr monument (see Fig. 5). Also, in the ninth-century Dar ul-Shafa cemetery opposite the Shirvani Mosque of Kashan is a Saadi poem on the tomb of Amir Emadeddin Mahmoud Shabli Shirvani. The grave of Mir Emad is in the form of a rectangle, with the Al-Kosar verse and the names of the 14 innocents inscribed in Regha calligraphy. The lower side of the stone has Saadi poetry (Silver 1966).

("Whoever came to the world will be mortal who will survive and remain, is God").

In ten other samples, the rock is a flat cradle type with a marginal inscription that has not been combined with arabesque designs around the gravestone (Fig. 6). On this gravestone, is written salivate on the 14 imams with Sol's calligraphy: "And salivate on the Imam Ali, Imam Hassan and Imam Reza... Imam Hussein al-Saied Karbala..." Similar examples of this theme written on Ahar Stone graves, have been seen on gravestones of the Safavid period, include Imamzadeh Ahmad Isfahan, Ardebil martyr (Shayesteh Far 2009), Charandab Tabriz (Mir Jafari and Bazaz Dastfrosh 2009), the Khezr Hamedan monument (Zarei 2002), Takht-e foulad-e Isfahan (Shahmandi 2013), as well as the Gorgan naharkhoran (Shayesteh Far 2009).

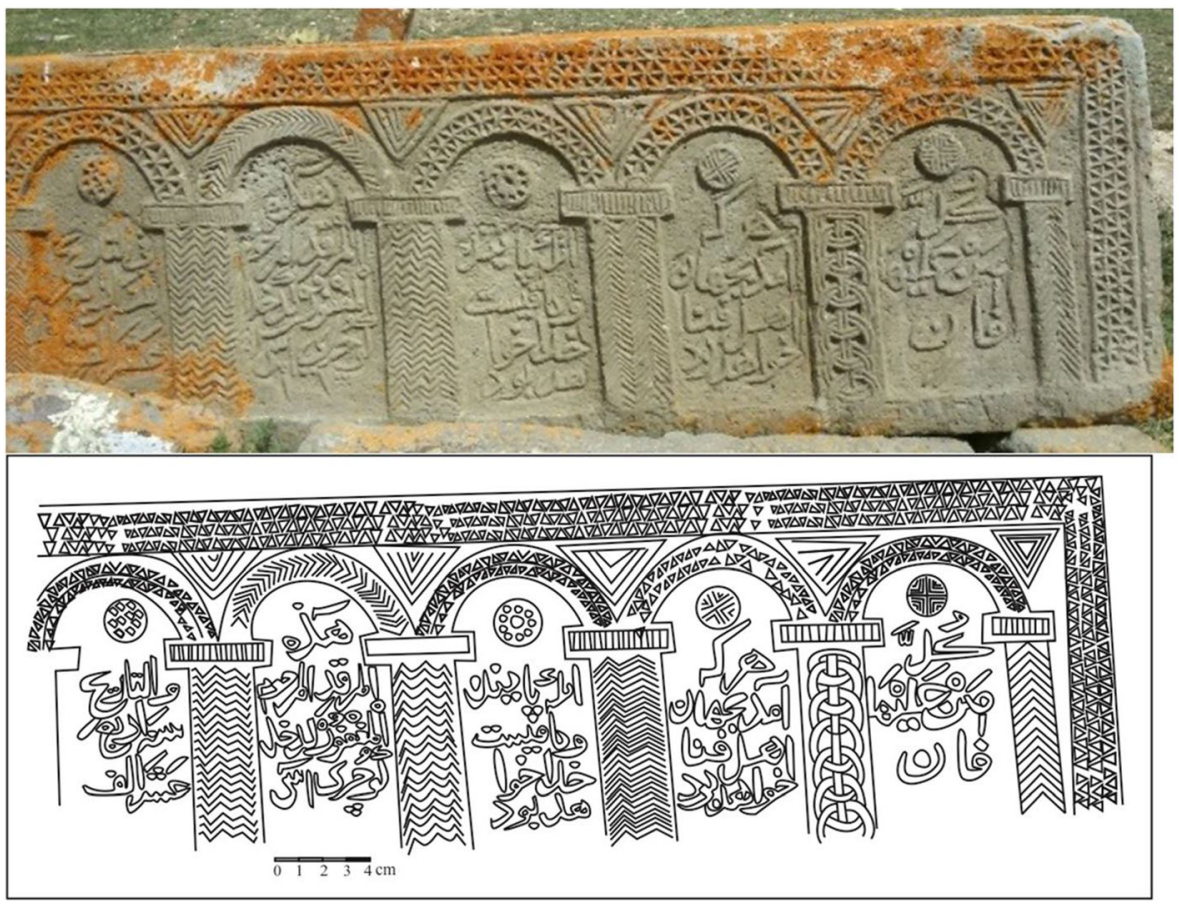

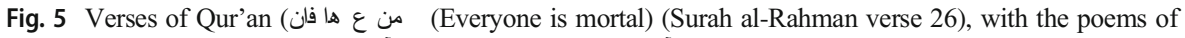

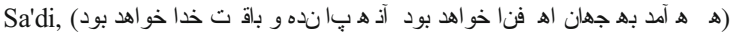


Geometric motifs. In Islamic art, in order to turn away from the materiality of the real word and draw closer to the divine truth, imagery is removed from its natural state and instead appears in a decorative and abstract way. Islamic art, which seeks meaning in a purposeful life, is the expression and embodiment of monotheism, and it is the geometry that adapts to these constitutions to create beautiful motifs. Muslim artists used and expanded geometric art to replace banned images of living entities while inviting the audience to spiritual thought. The development and development of geometric art was the result of the progress and position of geometry and science in the Islamic world. In the cosmology of Islam, geometric shapes describe cosmic dimensions and are manifested in holy art (Balkhari Ghahi 2006: 499). Understanding and interpreting these forms of reality leads humanity to the whole world and ultimately to the truth (Ardalan et al. 2000). Such precise polygonal motifs, carefully drawn on the basis of intricate geometric motifs, created a new clarity and abstraction in decoration.

Because the delicate geometric and star patterns can be repeated infinitely and arranged around numerous circular centers, they represent the implicit meaning of order (Najiboglu 2010: 144). For an artist who was supposed to decorate a surface, the geometrical structure was undoubtedly the most rational way, since these polygonal motifs are clear reference to the notion that divine unity or the unity of the divinity forms the background and foundation of the innumerable diverse worlds. In fact, the unity of divinity is beyond all manifestations, because the nature of the whole and the total does not leave anything outside of itself. It learns all and does not leave the latter. These polygonal motifs make clear reference to the notion that divine unity or the unity of divinity is the background and foundation of the infinite variety of the world (Bemanian 2011a, b).

Geometrical motifs are used in combination with other motifs on the Ahar Museum gravestones. One of the most widely used geometric forms on the gravestones is the circle - the most complete form and one that has a special symbolic significance throughout history.

In Islamic territory, the circle is a symbol of the creator (god), the straight line is the symbol of divine wisdom, the triangle is the symbol of the soul, and the quadrilateral is the symbol of matter. "In addition to the concept of perfection, the circle is a symbol of the world's creation and the concept of time. Circle is a symbol of the continuous motion of the sky and of divinity, and the spirit has also been introduced" (Pouyan and Khalili 2010: 106).

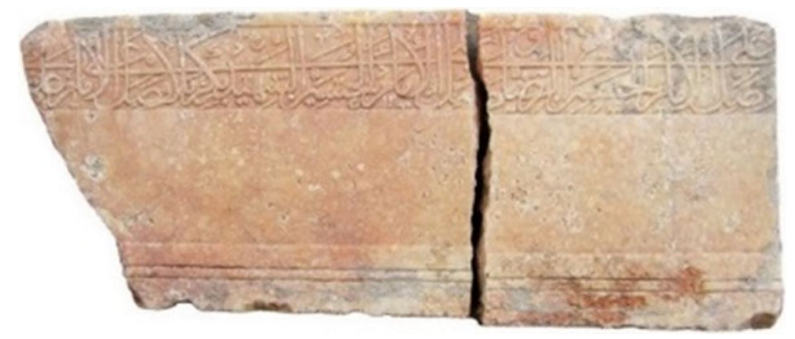

Fig. 6 Ahar Museum gravestone with salivate on the fourteen imams with Sol's calligraphy 
On the Ahar Museum's gravestones, the form of a circle is found in the form of five or seven-leafed geometric patterns (Table 3). This type of motif is a common geometric element on the Azerbaijan and Ardebil province gravestones. The presence of this element in all stone quarries and its absence in other mediums could indicate that this motif is considered an integral symbol of graves. This type of motif can be found as Safavid-era graveston decoration such as at the Tabriz Charanadab and Bilan Kouh cemeteries (Mirjafari and Bazaz Dastfroush 2009; 2012), the Pine_Shalvar cemetery (Qandgar 2017), tombstones in the courtyard of Sheikh Safiuddin Ardebili and Ardebil Shahidgah (Behshid and Bohloli Nuri 2013), in the village of Meshkinshahr Onar, and in the Armenian Cemetery at Tabriz (Shoja Del 2006). In all of these gravestones, the circular geometric pattern is executed in the form of seven fillings, and the choice of this number has been made consciously. Among Iranians, the number seven is a sacred and holy number. In particular, this number has a high rank and personality in Sufism. Numbers like seven and 40 are linked in the imagination with a halo of sacredness and consolation, enjoying a high degree of honor and dignity in Iran and Islam. In general, sevens are famous and have long been used by different ethnic groups for divine affairs (Hassanzadeh 2007). In Aryan astrology, the introduction of this number is as follows: "The number seven is the symbol and essence of selflessness, morality, illumination, compassion, purity, brightness, and essence of the Creator, the power of creation and the universe and spirituality. Seven, the magic number, is in line with the movements of the higher being and wins the wisdom, and anyone who is amazed by the number seven is pleased "(Shaifizadeh 2004: 164; also see Hassanzadeh 2007). According to Quran verses and commentators on the Hadith, the highest degree of spiritual happiness is entering the seventh floor of Paradise. Muslims believe in the existence of seven classes or the stages of forgiveness and paradise. These seven classes are the ones that Prophet Muhammad has carried over on the night of his ascension. In Islamic thought, the first full number is seven, and by refererence to surah, such as Baqara, Joseph, and Bani Israel. We find the magnitude of the number seven. "Many verses in the Qur'an can be found that all the signs of the creation of the heavens and the earth and their solidity under the divine command are on the number seven, indicating the lack of change and transformation in divine creation, and a reason for the sacredness of the perfection of this number: the heavens and the earth both Has seven floors and seven properties (angels) are in charge of the other manifestations of the presence of this number in Islam." (Sadegh Zadeh 1997: 69-71; also see Asadian 2005: 65).

Other geometrical motifs include candlelight and stars, which are among the most commonly used forms on the Ahar Museum gravestones. The hexagonal star is commonly seen in Azerbaijan, and it is usually used at the entrance of the shrines, for example at Sheikh Shahabuddin Ahari, the tomb of Sheikh Heydar Meshkin Shahr, and the tomb of Sheikh Safi Al-Din Ardebili. All three of these monuments appear in the Ilkhani era, and later developed during the Safavid period. The use of a hexagonal star on the Ilkhanid-period gravestones is more common in the other periods, but even this motif is executed on this period's coins. This motif can be found in many of the Ilkhanid-period gravestones such as at the Zawragh Bonab cemetery, the Sheikh Safiuddin Ardebili cemetry, the cemeteries around Mount Sahand in East Azarbaijan province (Ghandgar 2017), the Meymand Fars cemetry (Bozorgnia 2010), and Khazar Hamedan (Zarei 2002) (Table 4). The use of geometry in Islamic architecture and art in 
Table 3 Gravestone with geometric patterns, seven carved leaves Patterns

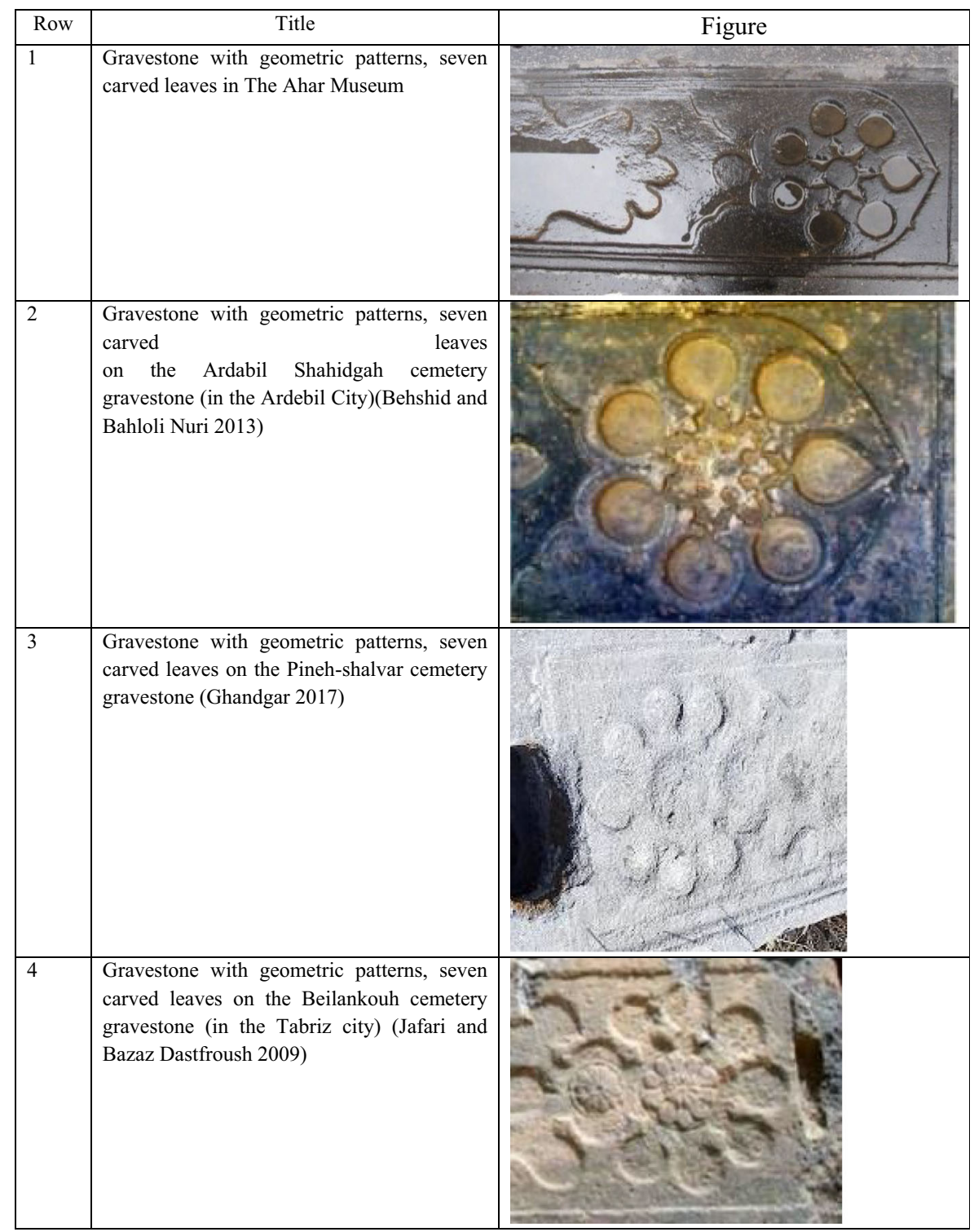

the Ilkhani period reached glorious heights, and was particularly important in this period.

In addition, religious laxity and lack of religious fanaticism led to the proliferation of various religious denominations, each of which has shown its ideology in works belonging to this period. The candle symbolizes the multiplicity of unity and unity in plurality. The multiplicity of manifestations of God's attributes are illustrated by many forms emitted from a single source. The Holy Qur'an also calls the radiating light of Allah " أهو نو ال اواتو ا" (“God is the light of heaven and earth”); therefore, in reality, 
the multiplicity is a symbol of God (Sattari 1997: 53). Just as the light of the star illuminates the darkness around it, the star of God is faith in the night to guide the believer to God. The motifs used in this gravestone have more in connection with the goddess and propagation of a divine sanctuary that forms in the form of stars. In the symbolic analysis of the six-pronged star, it should be recalled that in the ancient symbolic thinking of heaven, there are six planets with the sun in the center, six directions of space with an intermediate or central point forming the seventh direction, both representing the whole of space and time (Knight and Greben 2006: 557). The number six is the distance between the source and its emergence. The universe was formed in six days. Thus, six squares can be signs of creation (Knight and Greben 2006: 557). The four-legged, hexagonal, octagonal, and decoupled form, from a single circle, recalls thoughts of God to be derived from circular unity (Luller 1992: 85).

War instrument Motifs (bow and arrow) In eight of the Ahar Museum gravestones, the motif of the bow and the arrow is seen in various forms. Arrows and bows have long been a subject for depictions in the stone carvings of different regions, either in the hands of a hunter or represented singly in a more symbolic sense. On the Ahar Museum gravestones, both of these are depicted (Table 5). This type of motif is most commonly found in the gravestones originally from the Bohoul village cemerery. Depictions of archery have a long history in Iran's literature and art. One of the most important is the tale of a conflict between Rostam and Esfandiar in Ferdowsi's Shahnameh, in which arrows are considered a symbolic representation of an ancient temporal pattern in relation to the phenomenon of rain, in which the rain goddesses rise to confront the demons and causes the rain to fall. It contains a skydiving, rooting, eye and gaz tree as effective elements at the height of the symbolic story and can be read as a reminder of common mythological concepts among the Indo-European tribes in relation to rain and drought. Mitra hits the rock, spear, wood or sharp object on the rock, and the lands that are caught in the drought are saved. If the storytelling of Esfandiar's eyes in this narrative is a metaphor for dry eyes, and the routine of metaphor is from hard rock-related elements of water in Iran's thought, such illustrations themselves are reminiscent of deeply ancient concepts. This is due to archery and the flow of water (Razi 2002: 392). In the Islamic period, symbolic bows and arrows are shown placed in the hands of individuals (such as the gravestones of the Has village), as well as being depicted singly. The Seljuk kings used the eagle and archer to decorate their flags which were decorated with an archer or an eagle (Speller 1990: C 2, 132). Also, during the Safavid period, archers and arrows were important. Archery was highlighted in the arts of this era, and the beam and arch had symbolic places. In addition to the symbolic position of the beam and arch some parts of the Safavid armies, including the gourmets, used guns and armor, which was a sign of bravery and chivalry (Delavleh 1968: 348; Minursky 1955: 52). One of the traditions of the Safavid period was the writing of a prayer on the main beam of the bow, including "Saalhof" and "Yaslkhuda" (Bayhaghi 2009: 2479).

The Altar motif In all of the examples of the flat cradle graves, the motif of the altar exists as a framing device around the entire gravestone, and only in one instance does the altar motif surround just the upper part of the gravestone. The altar is one of 
Table 4 Tombstones with hexagonal stars

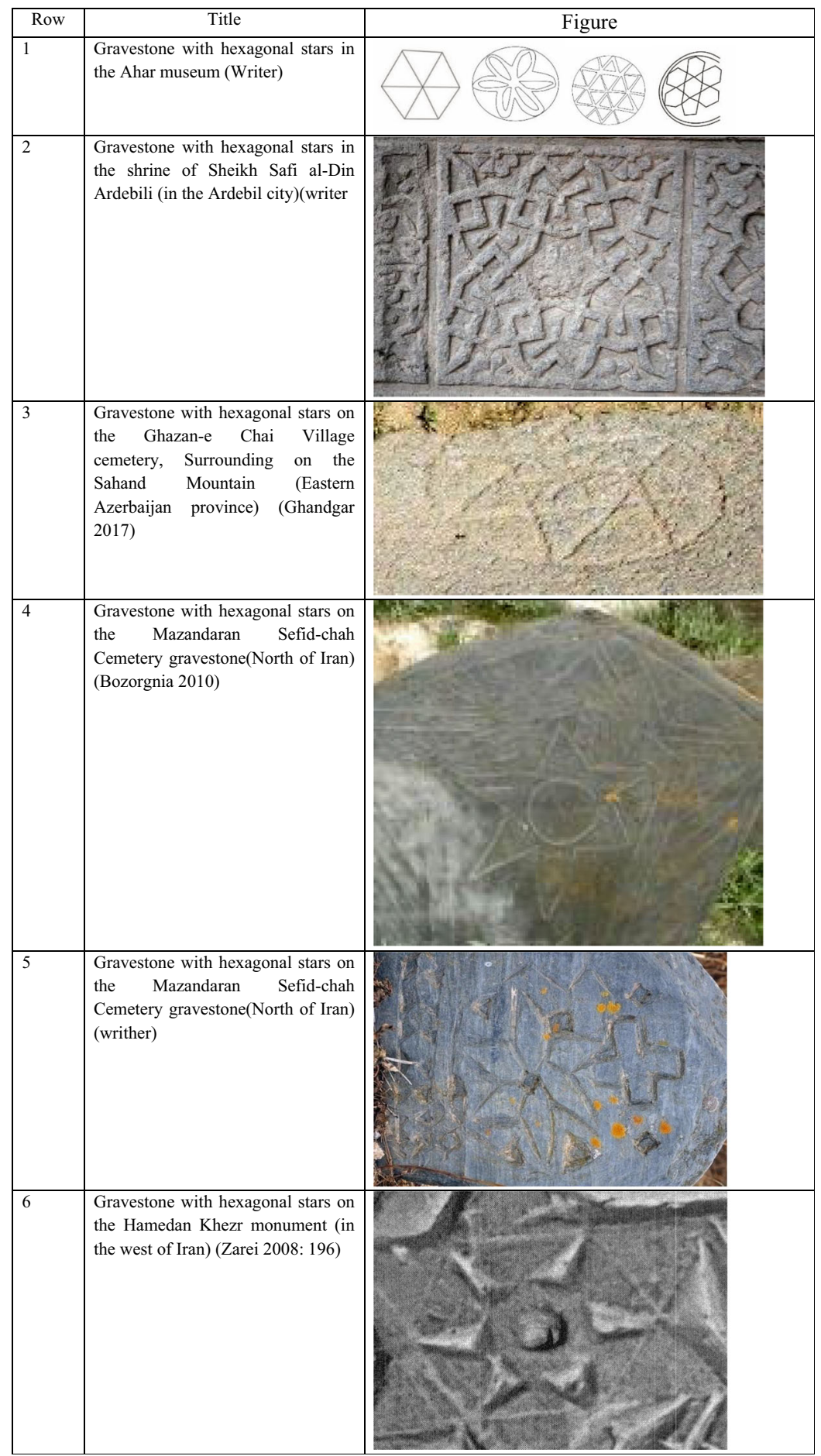


Table 5 Arch and Arrow on the gravestones

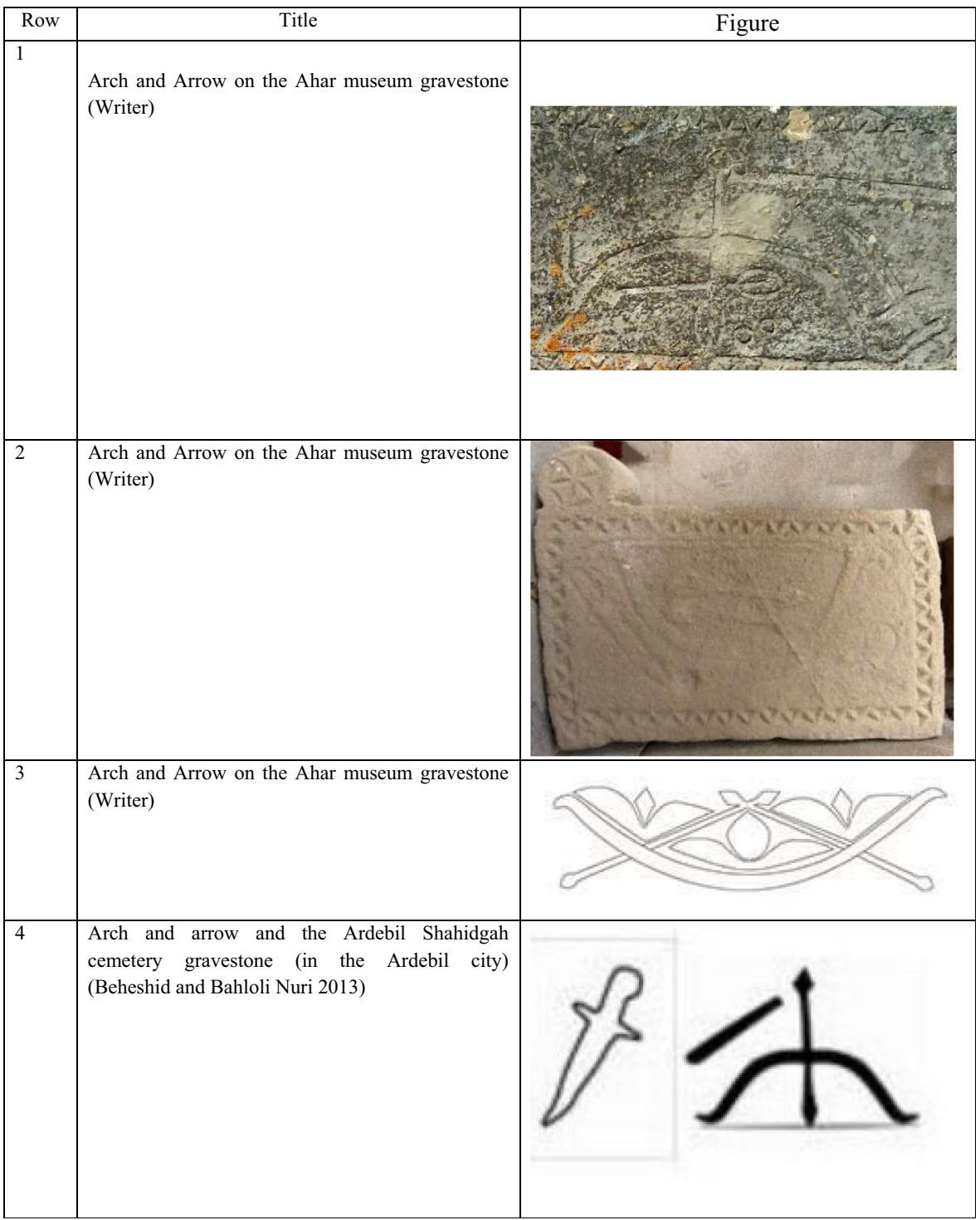

the few symbolic forms that can be explicitly explained in religious terms, and this type of motif exists in most of the cemeteries of the Azeri region and Ardebil. The altar is one of the main elements of the mosque, and it has also come to pass in the Islamic culture as a symbol of the gate of paradise.

In Islamic belief, the altar is the place of the manifestation of God, the symbol of light and of movement from the material earth to the supreme kingdom, and a door that can be the boundary of the inner, natural world and the external, evil world. This sign represents the connection of the world of the dead and the living, and the opening of this holy door marks the opening of the doors of paradise that the soul enters through 
beyond the world of disbelief and evil. In Islamic culture, the Prophet and the infallible Imams hold the gates of paradise. They open them for believers and on the eve of man's journey at death between the two worlds of the earth and the sky. The presence of angels, verses, and hadiths around these altar porches signifies where the human passage from the mortal world remains (Table 6).

Narrative Motifs One of the most remarkable points about the stone carvings of the Ahar area is the presence of narrative scenes associated with the previous occupation of the deceased. A typical example of this can be seen in the Has village cemetery (in the Kalaiar region, eastern Azerbaijan province). In the Ahar Museum, there is a gravestone just like that of the Ac village showing the deceased on a hunt with weapons including a bow and arrow, a wallet, and other tools of warfare. Along with horses and hunting dogs, they are pursuing wild animals, such as mountain goats (Table 6). In another example, a person on horseback is looking for animals with a dog and carrying a sword belt. In these narrative scenes, the motif of humans and animals are illustrated alongside each other. The animals of the Ahar Museum gravestones can be categorized into two groups: domestic animals (horses, cattle, goats, sheep, and dogs) and wild

Table 6 Altar motif

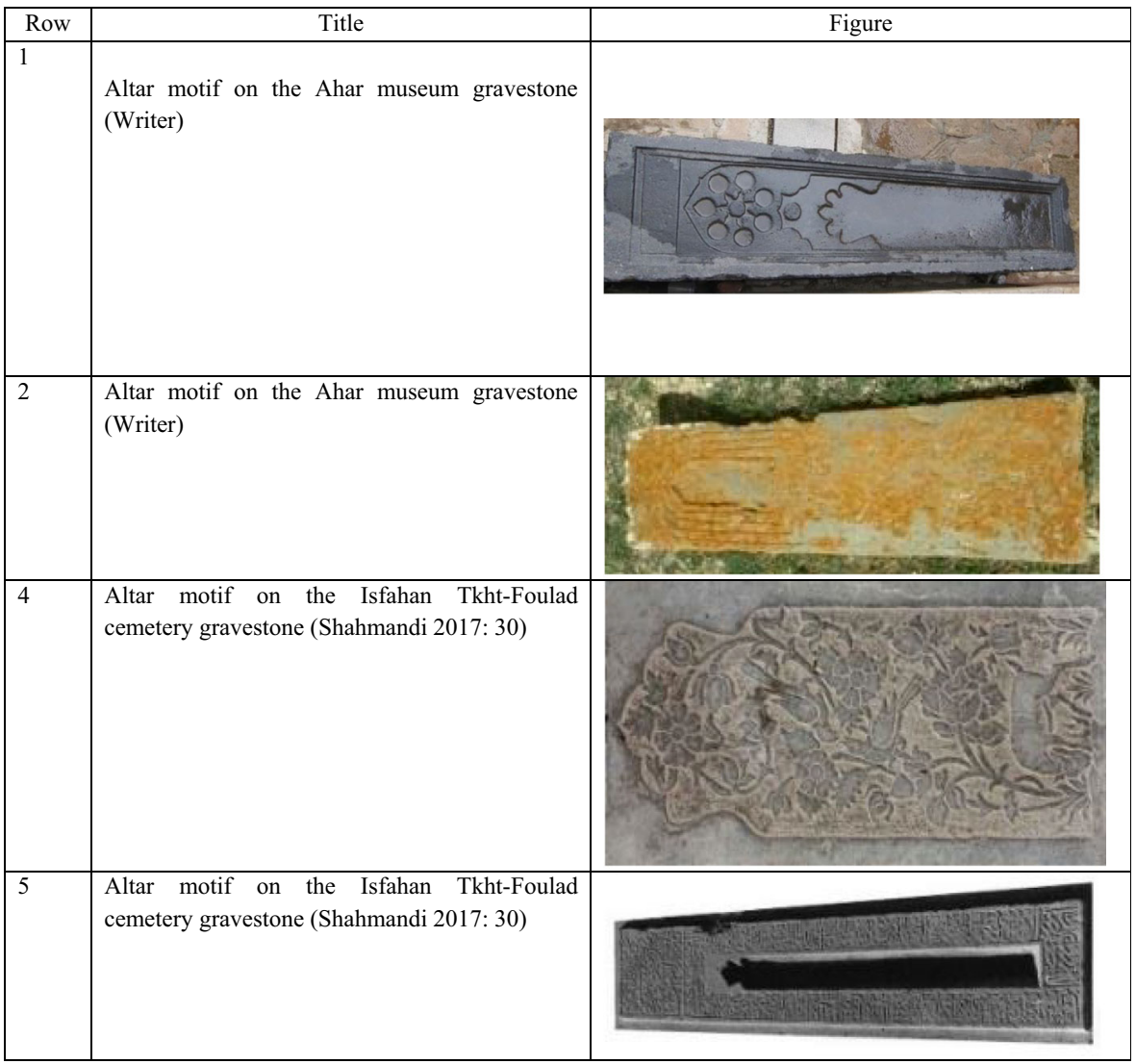


Table 7 Narrative Motifs on the gravestones

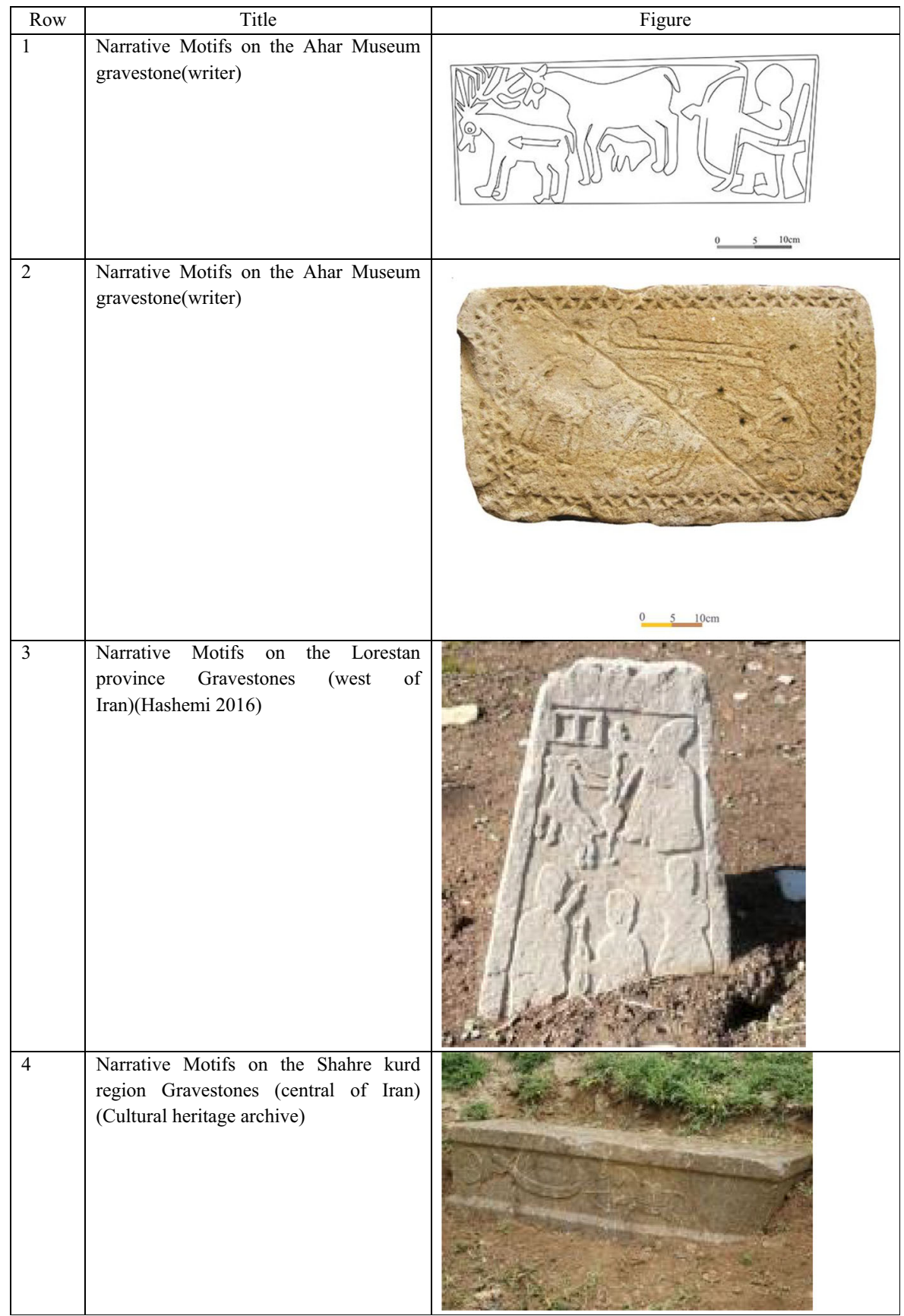

animals (deer and goats). It is difficult to distinguish between them exclusively by form due to a lack of precision in their carving and environmental weathering. Regarding the symbolic concepts of animals, it should be noted that among the animals mentioned, in 
Table 7 (continued)

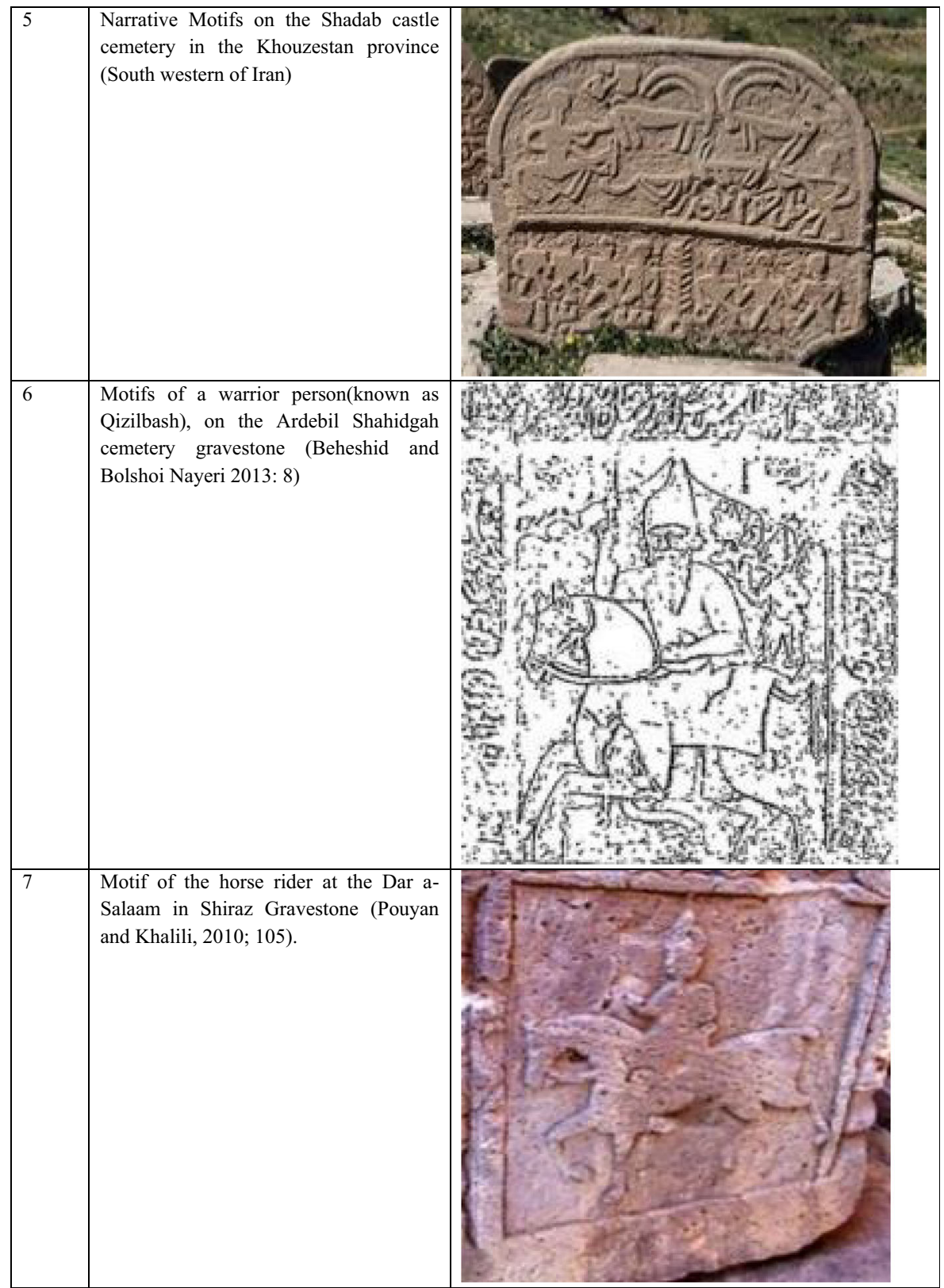

pre-Islamic mythology and ancient religious texts, horses have played a valuable role and have been praised. Apart from their common usage, such as for transportation and hunting, animals had ritual, economic, martial, artistic, decorative, and ritual functions. After Islam introduced the Qur'an and Islamic texts, many things have been said about the good nature and importance of these beings (Safi Khani et al. 2014). The deer is 
also present in all myths of the East and used as a symbol of femininity. The motif of the deer on the gravestone is usually found among plant designs or in a running scene. Islamic artists used the deer as a symbol of the fast and vigorous passage of human life (Fazli 2008, 312).

It should be noted that in most gravestones that include narrative and figural motifs there are images of the deceased's occupation. Examples of this type of motif in the west of the country can be found in the cemetery in Lorestan, on the gravestones of Ardebil province, especially in the cemetery of the martyr (Behshid and Bohloli Nuri 2013), in Khuzestan province at Shadab castle, in Markazi province, in Fars Province, in the Shiraz Darul-Islam cemetery (Pouyan and Khalili 2010) and in the province of Ilam in Helilan (Mortensen 1993) (Table 7).

\section{Conclusion}

The results of this study indicate the historical background of Ahar city. The works, monuments, and stone graves remaining in different parts of the city suggest the importance of this city in different historical periods. Studies show that the Ahar stone grave has existed since at least since the fifteen century CE with the Mongolian Ilkhans.

According to this study, most of the gravestones in the Ahar Museum belong to the Safavid period when the city of Ahar was of special importance. Perhaps the reason for this is the presence and gathering of scientists from around Iran and in the centers of the monument of Sheikh Shahabuddin Ahari. The stones in the Ahar Museum were categorized into five groups according to the design of the site, which include inscription, geometric, war material (arch and arrow), and the role of allegory and narrative.

Of the themes contained in the form of gravestone or signs in the form of volume, on the stone castle of the Ahar Museum, which has been closed down, the themes have been another tool for the stonecutter artist in expressing symbolic concepts. These elements are not merely decorative but have special meaning. These motifs are also manifestations of thoughts, feelings of folks who dealt with images and motifs with a symbolic perception and who knew the relation between the face and the meaning of the person's role. Inscriptions and geometric designs are one of the most important and beautiful elements of these stone blocks.

The verse of Sa'di, who conjures up the mortal nature of the world, recounts the Qur'anic verse with the educational and mystical aspect of the beliefs of a society to the world and life after death.

In this regard, the role of geometric elements, including the seven-facet, as well as the hexagon, which has been considered of a long time and has a special place in human beliefs, has played a role in another way, and in the symbolic conception of the highest degree of spiritual happiness Indeed, they are entering the seventh floor of Paradise for the deceased.

From the above-mentioned points, we are dealing with elements of the Shamseh and the stars that are the most precious stones in this gravestone. It is as if these elements are here to recount the plurality in unity and unity in plurality, which is one of the attributes of God. Also, as their name suggests, they associate the notion of light, as the Holy Qur'an also calls the light of Allah: "Allah, Noor al-samaū'at va-Al-Arz." So, in fact, the 
Shamseh and stars are a symbol of God. Other designs such as archs and arrows, as well as narrative scenes, highlight the courage and bravery of humankind and have immortalized these worthy human qualities through these designs.

Open Access This article is licensed under a Creative Commons Attribution 4.0 International License, which permits use, sharing, adaptation, distribution and reproduction in any medium or format, as long as you give appropriate credit to the original author(s) and the source, provide a link to the Creative Commons licence, and indicate if changes were made. The images or other third party material in this article are included in the article's Creative Commons licence, unless indicated otherwise in a credit line to the material. If material is not included in the article's Creative Commons licence and your intended use is not permitted by statutory regulation or exceeds the permitted use, you will need to obtain permission directly from the copyright holder. To view a copy of this licence, visit http://creativecommons.org/licenses/by/4.0/.

\section{References}

al-Wansaz-e-Khuyi, M. (2011). As Ghadim gravestones. Payam Bahrestan Journal 14:316-354.

Ardalan, P., Kazempour, M., and Ahmadi, H. (2000). Iranian Ceramics, Shamisa, Tabriz, Iran.

Asadian, S. (2005). Archaeological Survey in the Horand Plain. Tabriz, Iran.

Balilan Asl, L. and Doustar, F. (2015). Investigating the effect of farms on the development of the urban structure of Tabriz City from the Ilkhani to Safavid Period. Islamic Republic of Islamic Architecture 8: 6590.

Balkhari Ghahi, H. (2006). Theoretical foundations of Islamic aesthetics in the Holy Quran. Art Quarterly 70: 164-171.

Bayhaghi. (2009). History of Beyhaqi. Ferdowsi University Press.

Behshid, B. and Bohloli Nuri, B. (2013). The Concept of Engravings in the Tombstones of the Tomb of Sheikh Safi al-Din. National Archaeological Conference of Iran, Achievements, Opportunities, Damages.

Bemanian, M. R. (2011a). Application of Geometry and Proportions in Architecture, Heleh, Tehran, Iran.

Bemanian, M. R. (2011b). Application of Geometry and Proportions in Architecture, Heleh, Tehran, Iran.

Bozorgnia, Z. (2010). Tombstone in ancient cemeteries. Memar Magazine 63: 13-67.

De Morgan, J. J. M. (1959). Scientific French Delegation in Iran. Vadiei, K. (trans.), Chehr Press, Tabriz.

Delavleh, P. (1968). Safarnameh. Shafa, S., (trans.), Scientific-Cultural, Tehran, Iran.

Edinghausen, M. (2000). Survey in Ahar Plain. Shamisa, Tabriz, Iran.

Faqih Mirzaei, G., Mokhlesi, M., and Ali Habibi, Z. (2005). Takht-e Folad: Isfahan Historical Monument. Cultural Heritage Organization.

Fazli, A. (2008). Iranian Islamic Art. Shamisa, Tabriz, Iran.

Ghalich Khani, B. (2006). The Impact of Indigenous Beliefs on the Formation of Symbols Used in HandWoven Patterns of West Mazandaran (Case Study: The Art of Crochet and Mill Weaving). Mazandaran, Iran.

Gandgar, M. (2017). The Story of Tombstones with the Star of David in East Azerbaijan / The Smell of "Evil," Website, Modern Tabriz.

Hassanzadeh, A. (2007). The place of numbers in Iranian people's culture with emphasis on the number seven and forty. Iranian People's Culture 10: 166-189.

Hosaini, H. (2009). Comparison of the characteristics of the art of Safavid inscription painting in two collections of Iranian Shiite landmarks (the holy shrine of Imam Reza (AS) and the tomb of Sheikh Safi al-Din Ardabili). Islamic Art Study 11(6).

Hosseini, H. (2010). Introduction to the Sufi Mausoleum of Azerbaijan. Journal of Architecture and Urban Planning 2(43): 57-68.

Ingraham, M. L. and Sumarz, G. (1979). Settlements in the Meshkinshahr Plain, North-Eastern Azerbayjan, Iran, AMI.

Kabir Saber, M. B. (2009). Tabriz Islamic Gravestones. Islamic Crafts Journal 5(3): 8-15.

Kabir Saber, M. B. (2012). Islamic civilization stone arts in the Tabriz Armenian Cemetery (searching origination and explanation reasons). Bagh-e-nazar Journal 9(23): 75-82.

Kazempour, M., Omrani, B., and Rezalou, R. (2012). Large stone graves of Azerbaijan, according to new result of Zrdkhaneh study. Archaeological Study 4(1). 
Kazempour, M., Mohammadzadeh, M., and Shokrpour, S. (2021). The iconography analysis of the Islamic period grave stones in Ahar Museum. Honar-Ha-Ye-Ziba 21(1).

Knight, J. and Greben, A. (2006). Symbol Culture. Fazeli, S. (trans.), Jayhoun, Tehran.

Kroll, E. (1983). The southern Urmia Basin in the early Iron Age. Iranica Antiqua 40.

Kuhpar, M., Khanali, H., and Neyestani, J. (2015). Tombstone, a manifestation of the unity of different Islamic religions in Iran: typology, classification and study of rock cradle arrays. Journal of Islamic History 20:133-152.

Luller, R. (1992). Sacred geometry, metaphor of the world system. Art \& Architecture Quarterly 3: 76-85.

Minursky, V. (1955). Geographical Letters and Their Historical Roots in Atropatene (Media). Behzadi, R. (trans.), Lord, Tehran.

Mirjafari, H. and Bazaz Dastfroush, M. (2009). Charandab shrines of Tabriz. Textology of Persian Literature 1(4): 19-42.

Mirjafari, H. and Bazaz Dastfroush, M. (2012). BeilanKouh County. Historical Research (HistoricalCultural).

Moain, M. (1985). Farsi Culture. Amir Kabir, Tehran.

Mortensen, P. ( 1993). Survey in the Iranian Plain. Iran, AMI, 189-257.

Najiboglu, G. (2010). Geometry and Decoration in Islamic Architecture. Rozaneh, Tehran.

Nikzad, Z. and Asanranjani Kanari, I. (2005). Architectural Research of Hassanabad Historical Tomb or Bojar Oath - Imamzadeh Aqeel. 3rd Congress of the History of Architecture and Urban Planning of Iran.

Parsai, M. and Shahabi Rad, F. (2011). A study on the graphic symbols of Shiraz Darul Salam Cemetery. Book of the Month of Art 156: 68-75.

Pouyan, J. and Khalili, M. (2010). Semiotics of tombstones in Daraslam, Shiraz. Book of the Month of Art 144: 98-107.

Qandgar, M. (2017). The story of Tombstones with the star of David in East Azerbaijan / The Smell of "Evil". Published on the website of Modern, Tabriz.

Raja'i Alavi, S. and Vafa'I, S. (2009). Islamic Inscriptions of Gorgan and Dasht: Wooden Monuments and Inscriptions. Central Library and Information Center of Isfahan Municipality, Isfahan.

Razi, H. (2002). The History of the Mysterious Mithraic Religion in the East and the West: A Study in the History of the Mithraic Religion from the Beginning to the Present Age. Behjat, Tehran.

Sadegh Zadeh, B. (1997). Seven in the culture and religion field. Keyhan Journal 133: 69-71.

Safi Khani, N., Ahmadpanah, A., and Khodadadi, A. (2014). Semiotics of Tombstone Motifs in Isfahan Steel Throne Cemetery. Fine Arts-Visual Arts 19(4): 67-68.

Sattari, J. (1997). Mysticism and Sacred Art. Markaz, Tehran.

Shahinizad, M. (2011). Islamic Gravestones. Mirae Honar, Tehran, Iran.

Shahmandi, A. (2013). A study and comparison of the tombstones in the cemetery of Steel and Armenians of Isfahan. Fine Arts and Visual Arts 18(1): 33-44.

Shaifizadeh, A. (2004). Ahar City Architecture. Shamisa, Tabriz, Iran.

Shayesteh Far, M. (2009). Persian architecture and poetry engagement in the Timrod and Safavid periods, Islamic Art Studies 11: 79-104.

Shoja Del, N. (2006). Research on the Silk Road and caravanserais of this route in northwestern Iran.

Silver, S. (1966). The Iranian Carpet. Shamisa, Tabriz, Iran.

Speller, B. (1990). History of Iran in the First Islamic Centuries. Scientific and Cultural Publishing, Tehran, Iran.

Zarei, M. I. (2002) Tomb of Khezr in Hamedan. Journal of Works 33: 192-222.

Publisher's Note Springer Nature remains neutral with regard to jurisdictional claims in published maps and institutional affiliations. 